\title{
REGIONAL ECONOMIC GROWTH IN HUNGARY 1998-2005: WHAT DOES REALLY MATTER IN CLUSTERS?*
}

\author{
Balázs LENGYEL - Izabella SZAKÁLNÉ KANÓ \\ (Received: 31 July 2012; revision received: 6 August 2013; \\ accepted: 9 December 2013)
}

\begin{abstract}
Although industry clusters are major targets of regional economic development in less developed regions as well, we still need a deeper understanding of how the spatial clustering of firms generates dynamics in lagging regions. These latter environments may differ from the typical cluster policy examples that are usually specialised global centres of dynamically growing industries. Using census-type data of Hungarian firms, we test the effect of major cluster indicators - regional specialisation and spatial concentration of industries - and the impact of FDI on regional productivity and employment growth in Hungary. Our results suggest that regional specialisation does not affect regional growth, while the spatial concentration of industries is found to influence productivity and employment growth with an overwhelmingly negative effect. Furthermore, regional employment growth is associated negatively with the initial level of regional specialisation. Results suggest that Hungary has evolved into a dual economy in which previously specialised regions and geographically concentrated industries have lost their pace, while the main factor that favoured regional economic growth was the presence of large foreign companies. Therefore, economic policies fostering regional specialisation and the spatial concentration of industries - such as cluster policy - may have minor effects unless the interaction of foreign-owned and domestic companies is encouraged.
\end{abstract}

Keywords: agglomeration economies, industry clusters, foreign direct investment, regional productivity growth, regional employment growth, Hungary

JEL classification indices: J61, L16, O18, O47, P25, R11

* Balázs Lengyel acknowledges financial support received from the Hungarian Scientific Research Fund (PD106290). The work of Izabella Szakálné Kanó was supported by the European Union and

Balázs Lengyel, corresponding author. Research Fellow at the Centre for Economic and Regional Studies, Hungarian Academy of Sciences (MTA KRTK KTI) and International Business School, Budapest. E-mails: lengyel.balazs@krtk.mta.hu; blengyel@ibs-b.hu

Izabella Szakálné Kanó, Assistant Professor at the Faculty of Economics and Business Administration, University of Szeged. E-mail: kano.izabella@eco.u-szeged

0001-6373/\$20.00 @ 2014 Akadémiai Kiadó, Budapest 


\section{INTRODUCTION}

Following success stories that mostly originate from global economic centres, regional economic development in more peripheral countries tends to focus on specialised regions and spatially concentrated industries. These efforts are often called cluster policies and they are central in the smart growth initiatives of the EU2020 strategy as well as in the national development aims of member countries (EC 2011).

The idea of regional clusters is built on concepts that have since long been present in economics. Agglomeration economies have been considered as key factors in theories on regional economic growth (Marshall 1890; Isard 1956). The specialisation of regions and the spatial concentration of industries have been shown to be crucial to growth in major empirical findings of the regional growth literature (Glaeser et al. 1992; Henderson et al. 1995). The term cluster was coined by Porter $(1990,2003)$ who argued that local competition - typically observed in specialised regions - favours regional economic growth.

However, empirics are mainly based on develod economies, and theories need to be tested in other less developed regions as well, where the context might differ from the successful regions in many regards. For example, the interplay between co-located foreign and domestic companies might be decisive in Central and Eastern European transition economies. Regions that had been highly specialised during socialist industrialisation faced hard challenges in the post-socialist transition (Pavlinek - Smith 1998) and foreign-owned companies became a major driving force of growth (Radosevic 2002). Although multinational enterprises (MNE) are generally considered as major sources of local knowledge spillovers to local companies (Capello 2009b), domestic firms could rarely enter the supplier networks of these companies (Acs et al. 2007). A huge gap is found between MNEs and domestic companies in less developed regions and countries - the so-called dual economy - and automatic knowledge externalities are not likely to occur between the two spheres. Although the local effects of MNEs are crucial, these might depend on the institutional setting of industrial concentration (Gordon - McCann 2000) and on the mobile-immobile nature of production factors (Phelps 2004).

co-funded by the European Social Fund under the TÁMOP-4.1.1.C-12/1/KONV-2012-0005 project entitled "Preparation of the concerned sectors for educational and R\&D activities related to the Hungarian ELI Project". The authors would like to express their special thanks to Ichiro Iwasaki and Miklós Szanyi for their support, comments, and suggestions that greatly contributed to formulating previous versions of this paper. Additional comments have been received from Zoltán Bajmócy, Imre Lengyel, and László Szerb. The authors gratefully acknowledge the useful comments of three anonymous referees. All remaining errors are the authors' responsibility.

Acta Oeconomica 64 (2014) 
Therefore, we need a deeper understanding in how clusters drive economic growth in regions of less developed EU member states. In this paper, we use annual census-type data of Hungarian firms to examine the relationship between regional specialisation, spatial concentration of industries, and regional productivity and employment growth in Hungary between 1998 and 2005. We also look at the impact of foreign and domestic ownership to highlight the challenges policy-makers have to face.

The paper is organised as follows. Section 2 gives an account of regional development patterns in Hungary during the transition period. Section 3 provides an overview of how regional specialisation and spatial concentration is involved in the literature on regional economic growth, while Section 4 presents our hypotheses. Section 5 contains a description of the data used for this study and the empirical methodology. Section 6 conducts an empirical analysis of regional productivity growth and regional employment growth. Section 7 summarises major findings and claims that regional cluster policies can only have a minor impact in Hungary unless special efforts are made to foster interaction among foreignowned and domestic firms.

\section{THE CONTEXT OF RESEARCH: TRANSITION AND INDUSTRIAL DYNAMICS IN HUNGARIAN REGIONS}

The determining role of FDI, the remaining presence of some state-controlled services, and stagnating domestic companies are the main features of transition economies in their current development model (Szanyi 2003). In the first half of the transition period, from 1990 to 1995, a massive economic downturn occurred in Hungary. Big state-owned companies either went bankrupt or were privatised; the latter was followed by basic restructuring. Consequently, the unemployment rate, and especially long-term unemployment increased dramatically. MNEs started to carry out large investment projects in the tradable and services sectors (e.g. automotive and ICT) and in the non-tradable untraded sectors with secure local markets (e.g. energy and communications) of Hungary. Simple, cheap unskilled labour-based activities were developed by additional investments (Iwasaki 2007).

Economic catching up started from 1995, and the employment rate again approached the level of 1992 at the end of the period of our investigation. New, higher value-added activities were launched, which utilised local skilled labour and engineering talent; some of the foreign companies began to locate their R\&D functions to their Hungarian sites (Lengyel - Cadil 2009). From 1995-2003, the growth rate of business R\&D spending (BERD) by foreign affiliates was among the highest in Hungary (UNCTAD 2005). This process suggests that foreign affil- 
iates emerged as pools of potential knowledge spillovers, and thus they could serve as the main drivers of regional growth. However, in this prosperity period, regional spread of activities occurred in most of the industries (see Appendix 1).

Szanyi et al. (2011) described a structural process of the shifting activity of MNEs that was complemented by increasing local sourcing. Foreign-owned companies played a crucial role in spatial industrial dynamics through their supplier networks with indigenous firms. However, decisions about their regional networks were usually determined by the parent company headquarters abroad, and domestic suppliers played only a marginal role (Grosz 2006). Foreign firms tended to co-locate their activities, which meant that suppliers and competitors of these MNEs were mainly de-novo foreign firms that had followed their main partners into Hungary (Békés et al. 2009). Thus, a dual structure of economy has evolved in Hungary, which can be characterised by a sharp foreign - domestic gap (Farkas 2000).

The special development pattern of Central European transition economies determined their regional development as well. Lengyel - Leydesdorff (2011) showed that foreign-owned firms in high-tech and medium-tech industries restructured those regional economic systems in Hungary that went through the transition period relatively successfully. Other lines of regional analyses demonstrated that high labour productivity and employment levels resulted in strong regional competitiveness mainly in export intensive activities, determined by foreign-owned companies (Lengyel 2003). Regional catching up, the entry of foreign-owned companies, and the transition period itself created a unique field for testing regional growth hypotheses in economies that differ from developed ones.

In a previous study we found that regional specialisation resulted in slower employment growth, but proved that Marshall-Arrow-Romer type of knowledge externalities and the presence of large firms were decisive in regional value-added growth (Lengyel et al. 2010). The data is re-visited in this paper and we focus now on labour and total factor productivity growth. Another major difference compared to our previous paper is that among other crucial factors we control for the spatial concentration of industries. Furthermore, the present paper specifies more accurate variables and contains a more critical attitude towards clusters.

\section{REGIONAL ECONOMIC GROWTH: AN OVERVIEW}

Regional economic growth is currently mainly understood as a result of new products and services created in the region (Varga - Schalk 2004). The idea stems from new growth theories that turned technological development endogenous for economic growth (Romer 1986; Lucas 1988; Krugman 1991). This opened the

Acta Oeconomica 64 (2014) 
floor for regional growth theories that assumed local knowledge externalities to arise from company co-location and to have a major role in regional growth (Glaeser 2000; Varga 2007).

However, already Marshall (1890) reported that the presence of co-located companies provides benefits external to the firm, which were later differentiated as localisation agglomeration economies (local horizontal integration) and urbanisation agglomeration economies (lateral integration of co-located firms) in regional economics (Isard 1956). Both types of agglomeration economies are associated with local knowledge externalities and are therefore considered as sources of regional growth (Glaeser 2000). Local knowledge spillovers co-existing with other localisation economies are commonly referred to as Marshall-Arrow-Romer (MAR) externalities that appear in specialised regions, where firms have a similar technological and cultural background. On the other hand, Jacobs (1969) demonstrated that inter-industrial knowledge spillovers, referred to as Jacobs externalities, drive urban growth and therefore economic diversity should be regarded as a source of growth in large cities. The effect of local knowledge externalities on regional economic growth is frequently analysed with the help of regional specialisation and the spatial concentration of industries, which is the baseline of regional clusters.

Activity-complex economies have been recently added to the typology (Parr 2002; Capello 2009a), meaning that the vertical integration of the production chain of co-located companies reduces transaction costs. In a similar manner, recent literature on industrial clusters argues that agglomerations differ according to the mode of company entry and local interaction (Gordon - McCann 2000). For example, the "pure agglomerations" of large cities are open for entry and every firm can benefit from local knowledge spillovers, which might not be equally true for "industrial complexes" of smaller towns, where high transaction costs prevent new firms from entering the cluster. Thus, knowledge spillovers are not necessarily present in agglomerations; inter-firm learning depends not only on the industry characteristics of co-located firms, but also on their social, institutional, and organisational proximities (Boschma 2005; Gordon - McCann 2005; Iammarino McCann 2006).

Although capital accumulation is very central in economic growth models (Romer 1986), little attention has been devoted to the role of capital ownership in regional growth (Audretsch - Keilbach 2005). However, the transaction costs theorising of industrial clusters claims that local learning highly depends on the local institutional setting of firms that is a by-product of transaction costs involved in local activities (Gordon - McCann 2000). Following this literature, one may assume that company ownership is an essential feature and should be considered as a factor of regional economic growth. Put differently, an additional layer 
of communication difficulties can be assumed between firms with different ownership types, which are very important in our dual economy argument, but will not be tested directly.

The location behaviour and spatial effects of multinational enterprises has gained much attention in developed (Beugelsdijk et al. 2010) and in developing countries (Sjöholm 1999). MNEs have been widely analysed in terms of their augmenting effects on regional development and exploitation behaviour of regional resources (Young et al. 1994; Nobel - Birkinshaw 1998), as sources of local knowledge spillovers to domestic companies (Capello 2009b), the speed of local embedding considering their mode of entrance (Lorenzen - Mahnke 2002), and the learning processes in certain locations (Mates 2010).

However, the role of MNEs in regional growth divides scholars and it is still questionable whether MNEs have the same local impact in their home-base and in their subsidiary areas. To consider this problem in the context of regional economic growth, one has to be aware that MNEs have their effects on a larger geographical scale than domestic companies because they manage their resources on an international level (Phelps 2004). The company's investment strategy and the institutional setting of the local environment determine the level of local externalities (McCann et al. 2002). If the company chooses to locate in an industrial complex and optimises production output and minimises transaction costs, local externalities derived from MNE presence in cluster areas are more the exception than the rule (Phelps 2008).

The former statement has a special relevance in periphery areas, where MNEs are the engines of local economies; mostly standardised production is located in their subsidiaries, and a huge gap runs between foreign-owned and domestic firms. Therefore, the classic tests of agglomeration economies' impact on regional economic growth need a closer look, with distinguished ownership categories.

\section{THE HYPOTHESES}

As outlined above, ownership is a central issue in dual economies because of the huge gap between foreign-direct investments and domestic companies. Previous research found evidence on knowledge spillovers from foreign to domestic companies within industrial sectors at the national level (e.g. Iwasaki et al. 2009). Another type of analysis showed that geographical proximity matters in spillover from MNEs to domestic companies (Halpern - Muraközy 2007); also, more productive domestic firms are more likely to absorb knowledge spillovers from foreign-owned firms than less productive ones (Békés et al. 2009). However, we will touch upon ownership issues only in order to discuss the results we get from ana-

Acta Oeconomica 64 (2014) 
lysing industry cluster effects. Therefore, we focus on the regional specialisation and spatial concentration of industries in the hypotheses.

The economic transition has resulted in a sharp regional restructuring in Central and Eastern Europe (Petrakos 2001). In the particular Hungarian case, due to the monocentric structure of the economy, only few regions have become relatively dynamic: the agglomeration around Budapest and the regions between $\mathrm{Bu}-$ dapest and Vienna (Varga 2007). In a previous paper, we found evidence for the positive and significant impact of regional specialisation and local oligopolistic industry structures on regional production growth (Lengyel et al. 2010). Therefore, the specialisation of regions and the spatial concentration of industries will be tested by the formal hypotheses.

Hypothesis 1 (H1): Regional specialisation and spatial concentration of industries have a positive impact on regional productivity growth.

Hypothesis 2 (H2): Regional specialisation and spatial concentration of industries have a positive impact on regional employment growth.

According to the expectations drawn from the regional cluster literature, as discussed in detail in the above, regional specialisation and the spatial concentration of industries favour regional economic growth because of the positive externalities arising. However, the specific dynamics in transition economies and the sharp gap between foreign and domestic companies may alter these effects, which is a central point in our argument.

\section{DATA AND METHODS}

The information used for the empirical analysis was collected from the annual census-type data of Hungarian firms, which were compiled from financial statements associated with tax reporting submitted to the National Tax Authority by legal entities using double-entry bookkeeping. The observation period covers the years from 1998 to 2005. The data include all industries and contains basic information for each sample firm, including the NACE 4-digit industrial classification codes, the annual average number of employees, total turnover, production costs, and other major financial indicators. The locations of the sample firms are identifiable. Information about the ownership structure includes the total amount of equity capital at the end of the term and the proportional share held by domestic private investors and foreign investors.

To empirically examine the hypotheses, we aggregate the above firm-level data by industry and by region. We use the industrial classification following the 
cluster study by Ketels - Sölvell (2005). To deal with the whole national economy, however, we complement their list of industries with a few other sectors. ${ }^{1}$ The final list consists of 41 sectors. Regional aggregation is conducted by the 168 local administrative units (LAU1) in Hungary. Thus, the total number of observations is $6,888(168 \times 41)$. We exclude observations if the total annual employment included fewer than 10 persons at the beginning of the period. As a result, a total of 3,777 observations are left out of our dataset and 3,111 remained in our sample. We also eliminate observations containing missing values that pose an impediment to our empirical analysis. Sub-regions that have less than 50,000 inhabitants are also excluded from the sample in the last step of analysis in order to avoid the disturbing effect of rural regions (Lengyel 2011).

While the analysis contains all the sub-regions in half of the models, only 9 sub-regions are excluded from the regression models in later steps. However, the last models that are aimed to investigate urbanised regions include only 55 sub-regions out of 168 (see Appendix 2). Manufacturing and service sector industries are represented in high numbers in our investigation, while agriculture, mining and energy, and construction services represent a minor share (see Appendix 3).

Three types of explanatory variables will be used in the models: (1) regional specialisation variables, (2) variables of industrial concentration, and (3) ownership variables. Only those industry-regions will remain in the sample that have both foreign and domestic companies when introducing capital variables.

Several methods have been proposed for measuring regional specialisation (Ratanawaraha-Polenske 2007; Nakamura-Morrison Paul 2009). Among them, the location quotient (LQ) indicator of relative industrial concentration in the region is the best known and it is very often associated with industrial clusters. In this paper, the value of the $\mathrm{LQ}_{\mathrm{E}}$ indicator reflects the relationship between the labour share of industry $i$ in sub-region $r$ and the share of the industry in the entire Hungarian national economy following the formula $\mathrm{LQ}_{\mathrm{E}}=\frac{E_{i r} / E_{r}}{E_{i} / E}$, where $E$ denotes number of employees in the given subset. We also calculate the $\mathrm{LQ}_{\mathrm{F}}$ indicator for the relative concentration of firms using the formula $\mathrm{LQ}_{\mathrm{F}}=\frac{F_{i r} / F_{r}}{F_{i} / F}$ where $F$ is number of firms. In the empirical analysis, we use the log transformed value of the $\mathrm{LQ}_{\mathrm{E}}$ and $\mathrm{LQ}_{\mathrm{F}}$ indicators as Employment Specialisation (SPECEMP) and Organizational Specialisation (SPECORG) variables. A positive effect of $\mathrm{LQ}_{\mathrm{E}}$ and $\mathrm{LQ}_{\mathrm{F}}$ on regional productivity growth was found in a previous paper (Lengyel et al. 2010).

1 Newly added industries consist of (a) public services, (b) real estate services, (c) healthcare services, (d) other manufacturing, and (e) other consumer services.

Acta Oeconomica 64 (2014) 
The group of concentration variables contain three indices: Sales Concentration (CONCSALE) is measured by a sub-regional level Hirschman-Herfindahl index calculated from national market-share distributions following the formula $\mathrm{H}=\sum_{i=1}^{N} s_{i}^{2}$. Market share $\left(s_{i}\right)$ is defined as the firms' share in the total net turnover of the industry-regions. The higher the indicator, the more concentrated the market and therefore the stronger the dominance of big firms in the industry-region. Employment Concentration (CONCEMP) is approximated by the average firm size in the industry-region CONCEMP $=\frac{E_{i r}}{F_{i r}}$. Although this indicator is not a concentration indicator per se, it is frequently used to measure the internal economies of scale. Therefore, we use it to indicate economies of scale that are internal to the industry-region. Industry Concentration (CONCIND) is a national level Ellison-Glaeser $\gamma$ index that has been calculated from regional employment data for each industry following the formula $\gamma=\frac{G-H}{1-H}$. This index is composed from the indicator of the spatial concentration of firms in the given industry measured by the raw concentration of employees $(\mathrm{G})$, and from the Hirshman-Herfindahl Index $(\mathrm{H})$ measuring the firm level employee concentration in the industry. The Ellison-Glaeser $\gamma$ index is used to indicate economies of scale that are internal to the industry, but external to the industry-region. The higher this latter indicator, the more concentrated the industry in certain regions, while a low number indicates that the industry is dispersed across regions.

Ownership measures are categorised into four variables aggregating proportional shares of foreign and domestic ownership in the companies' capital at the industry-region level. Initial values of Foreign-Owned Capital (FORINI) and Domestically-Owned Capital (DOMINI) are log-transformed. Dynamic values of investment are also included in the capital variables: Foreign Growth (FORGRO) and Domestic Growth (DOMGRO) are the change in the natural log of registered foreign and domestic capital over the period. An opposite effect of domestic and foreign firms on regional growth will be demonstrated in the paper.

The detailed definition and descriptive statistics of the variables used in the empirical analysis are reported in Table $1 .^{2}$

The goal of our empirical analysis is to regress growth in Labour Productivity (LPGRO) and Total Factor Productivity (TFPGRO) of firms operating in the $i$ th industry of the $r$ th region into the above independent variables. Control variables include indicators that are frequently entered into regional growth models: the Initial Level of Employment and Growth of Employment in the region-industry

2 Value added is computed by total net turnover (total material costs + total amortisation). 


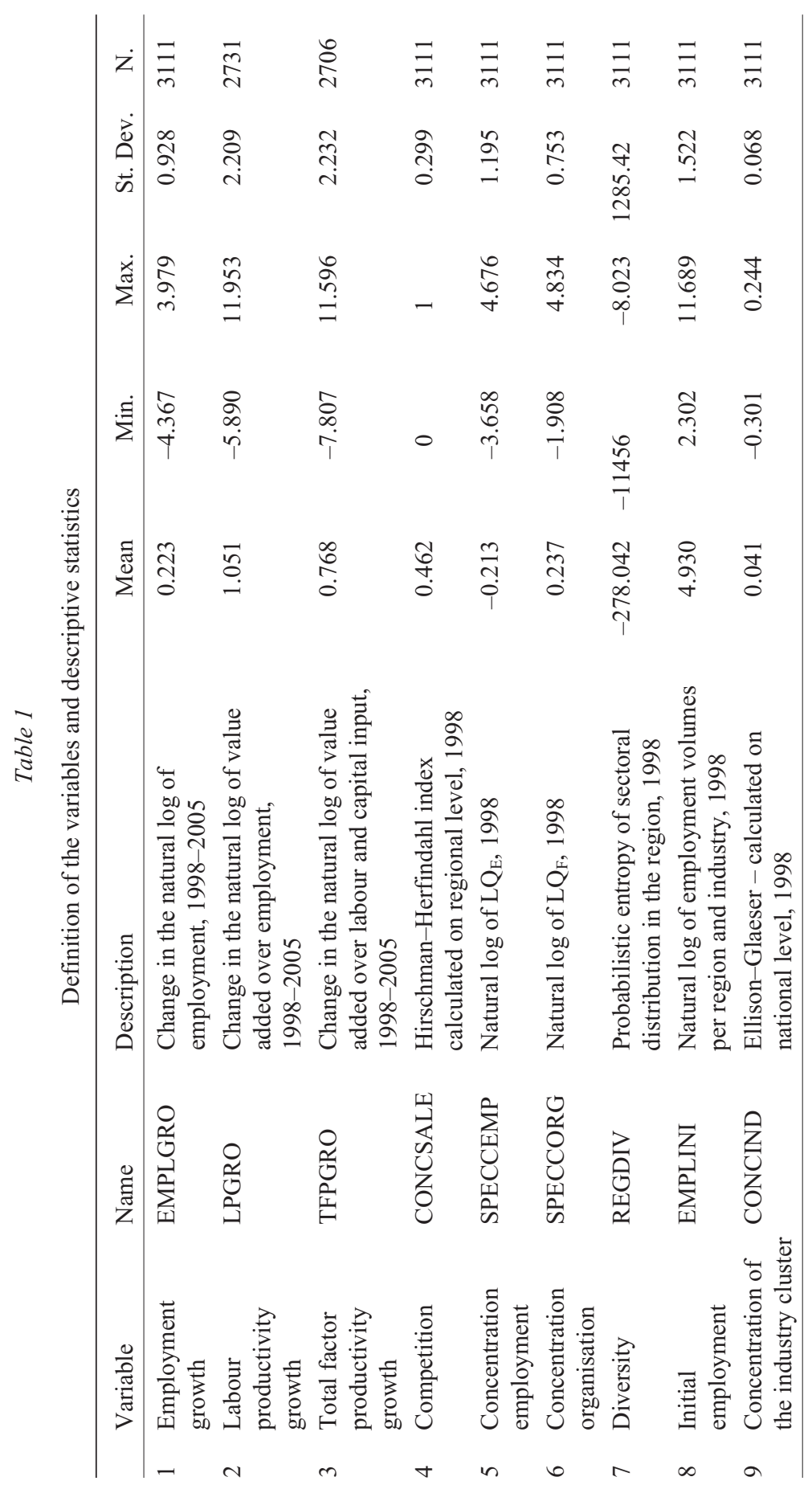

Acta Oeconomica 64 (2014) 


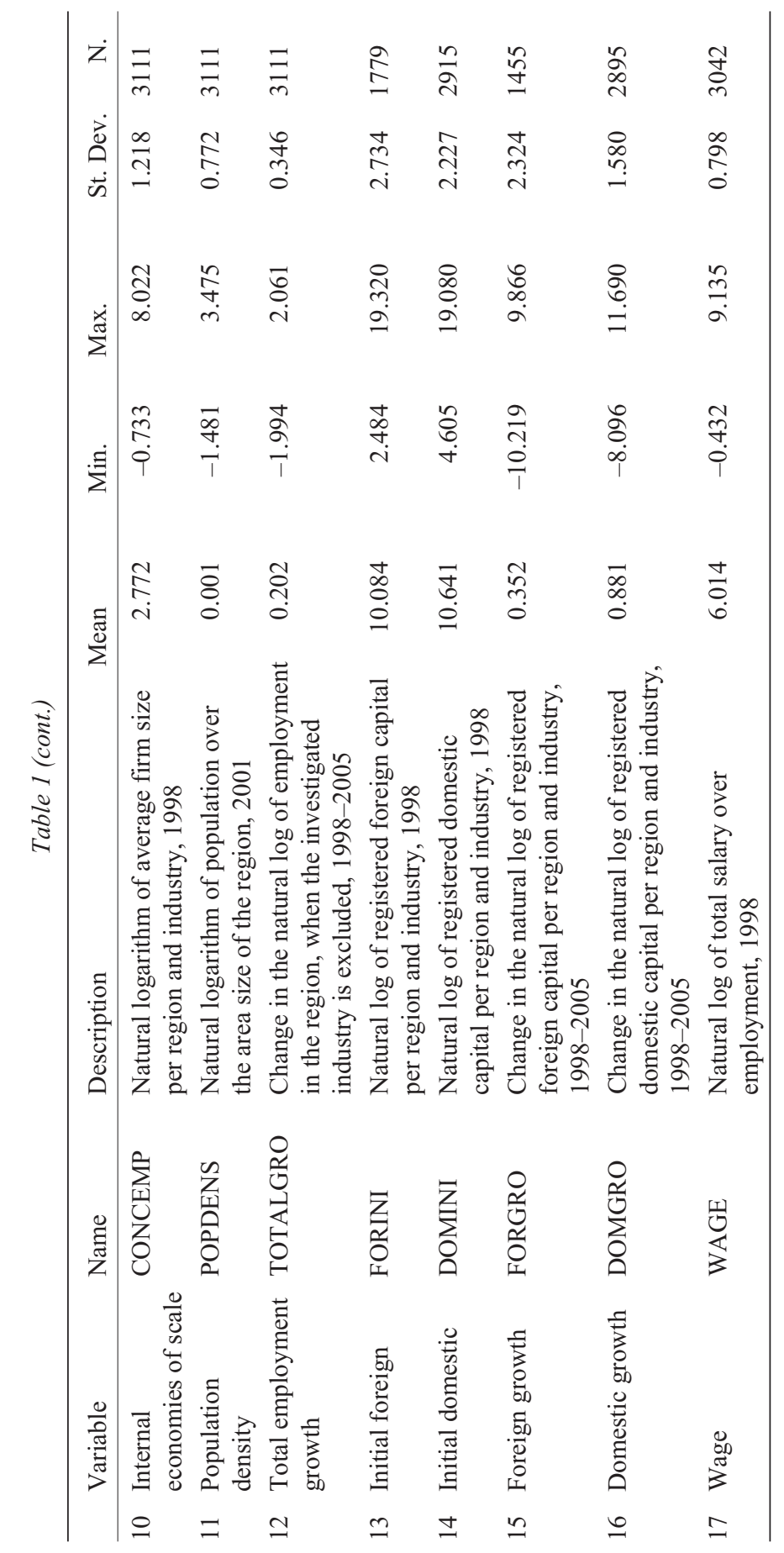


(EMPLINI and EMPLGRO), and Regional Economic Diversity (REGDIV) that is an entropy measure of firm distributions across the industry classifications in the region. Population Density (POPDENS) is applied to examine the impact of urbanisation on regional economic growth.

In the next step of the analysis, we turn to employment growth models where the explanatory variables are the same as the ones used in the productivity growth models. However, we use the control variables that are emphasised in the literature of urban and regional growth (Glaeser 2000): the Initial Level of Labour Productivity and Growth of Labour Productivity (LPINI and LPGRO), and the Initial Level of Total Factor Productivity and Growth of Total Factor Productivity (TFPINI, TFPGRO), respectively. These variables are aimed to capture the location-specific productivity features, which are thought to lead to employment growth by attracting companies to favourable locations. We also take the Initial Level of Employment (EMPLINI) and the level of Employment Growth in the Region besides the industry in focus (TOTALGRO). The latter variable captures the growth in local demand (van Oort et al. 2005).

We also add a WAGE variable to the analysis that captures the differences in average salary across sectors and regions. We had difficulties in applying land price deflator indexes that are essential elements of traditional growth regression. Thus, we use POPULATION DENSITY (POPDENS) to capture the effect of urbanisation on regional economic growth. Productivity variables correlate very strongly with each other (Table 2); therefore, they are used in separate models and only those are reported that have a significant effect.

We estimate the above regression equations using the OLS method. Standard errors are adjusted for sectors by the clustering method. Unlike in a previous paper (Lengyel et al. 2010), here we follow Glaeser $(2000,90)$ and apply area-specific random effects instead of fixed effects.

\section{RESULTS}

First, we introduce how firm ownership, foreign and domestic capital in particular, affects regional growth in a dual economy. Second, Hypothesis 1 will be tested concerning the role of regional specialisation and spatial concentration of industries in regional productivity growth. Third, Hypothesis 2 and the role of specialisation and concentration in regional employment growth will be tested. 


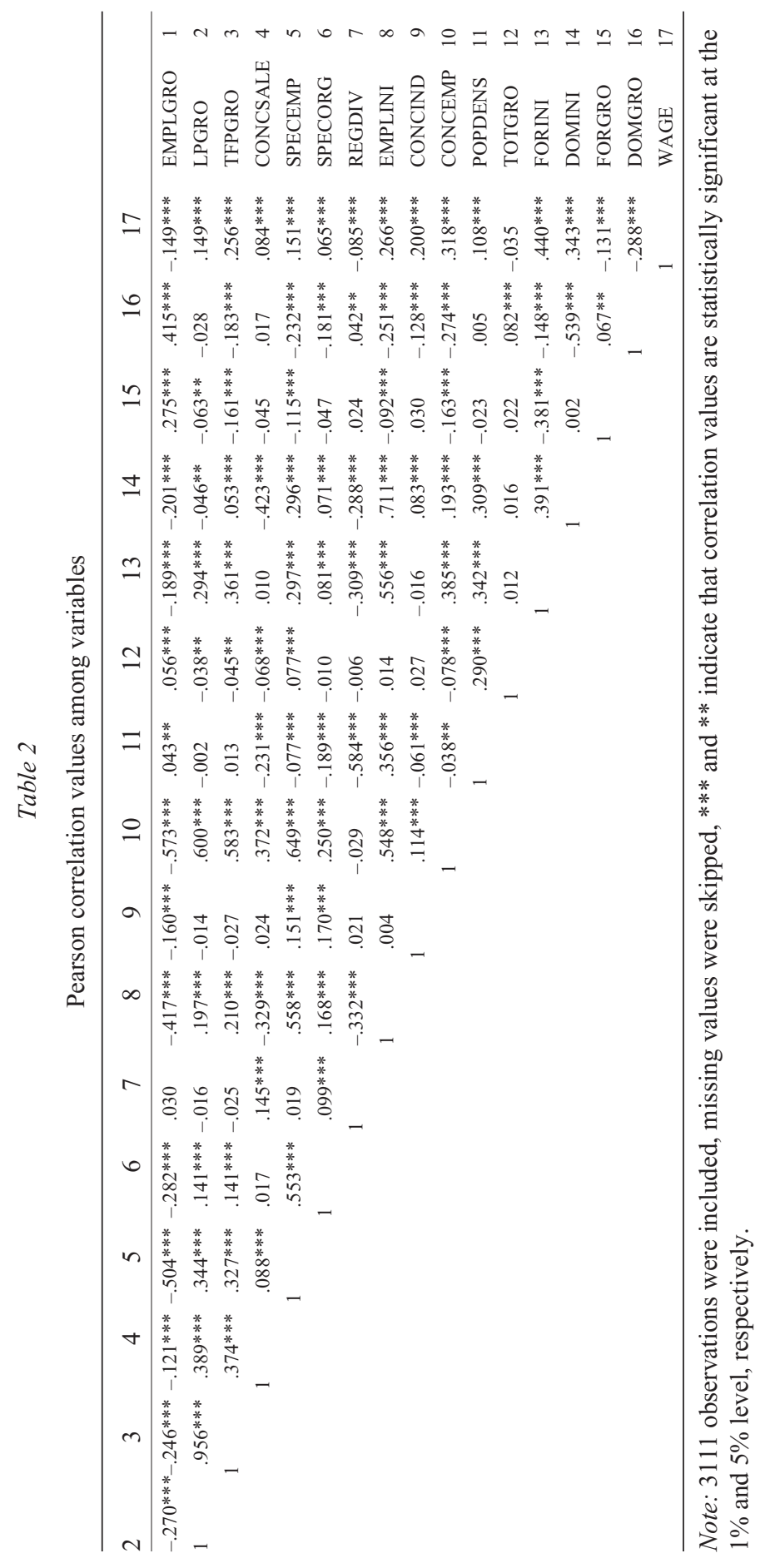

Acta Oeconomica 64 (2014) 


\subsection{Firm ownership}

As we expected, a very sharp conflicting effect of capital variables is found that illustrates the dominance of foreign-owned companies in regional productivity growth (Table 3).

The initial values and growth of foreign-owned capital have a positive effect on regional productivity growth, while the initial values and growth of domestic capital have a negative effect. No such contrast regarding the effect of foreign and domestic capital can be identified in regional employment growth. This latter dependent variable seems to be negatively affected by the initial level of foreign capital and a positive impact of growth in both types of capital is found.

Table 3

Regional growth and firm ownership

\begin{tabular}{lccc}
\hline & Labour productivity & Total factor productivity & Employment \\
\hline const & $1.077^{* * *}$ & $0.779^{* *}$ & 0.030 \\
& $(2.99)$ & $(2.20)$ & $(0.22)$ \\
DOMINI & $-0.310^{* * *}$ & $-0.304^{* * *}$ & 0.015 \\
& $(-9.79)$ & $(-9.76)$ & $(1.36)$ \\
FORINI & $0.339^{* * *}$ & $0.354^{* * *}$ & $-0.019^{* *}$ \\
& $(14.166)$ & $(14.98)$ & $(-2.24)$ \\
DOMGRO & $-0.209^{* * *}$ & $-0.329^{* * *}$ & $0.227^{* * *}$ \\
& $(-4.815)$ & $(-7.70)$ & $(14.21)$ \\
FORGRO & $0.099^{* * *}$ & $0.023^{* * *}$ & $0.080^{* * *}$ \\
& $(3.926)$ & $(0.92)$ & $(8.54)$ \\
\hline$N$ & 1311 & 1311 & 1404 \\
$R$-squared & 0.146 & 0.189 & 0.223 \\
$F$-test & $56.145^{* * *}$ & $76.144 * * *$ & $100.780^{* * *}$ \\
\hline
\end{tabular}

Note: All the models are estimated using OLS regression. $t$-statistics are reported in parentheses beneath regression co-efficients. ${ }^{* * *}$, and $* *$ denote statistical significance at the $1 \%, 5 \%$ levels, respectively. For definitions of variables, see Table 1.

The static and dynamic capital variables, whether foreign or domestic, show a very similar distribution. The static values are of a very similar and only positive interval, with a mean and standard deviation of 10.11 and 2.71 (foreign), and 10.58 and 2.24 (domestic). Capital growth measures vary across negative and positive values, both the foreign and domestic indicators have the mean around zero $(0.31$ and 0.72$)$ with a standard deviation of 2.33 and 1.69 , respectively. A very important difference between the foreign and domestic variables is the number of observations: foreign investments were present only in half of the regions where domestic companies existed. Therefore, the models of Table 3 zoom in on the regions where foreign and domestic companies co-exist in the same industries.

Acta Oeconomica 64 (2014) 
While FORINI has a positive and significant impact on both LP and TFP growth, DOMINI affects productivity growth adversely. The controversial effects of the initial values of capital imply that labour productivity growth occurred in regions where the initial concentration of foreign capital was high. High concentration of domestic capital resulted in decelerated labour productivity growth. TFP was calculated from a simple Cobb-Douglas production function; therefore, the association values indicate that regional production increased faster where the level of foreign capital was relatively high and domestic capital was relatively low in 1998. The dynamic values of foreign and domestic capital, FORGRO and DOMGRO, similarly have controversial effects. The negative effect of DOMGRO indicates that the faster the growth in domestic capital, the slower the TFP growth. The negative effect of domestic investments on productivity growth means that the rise in domestic capital was faster than the increase in output.

Foreign-owned companies had two main entry modes in Hungary: either they bought existing facilities of formerly state-owned companies in the privatisation process, mainly in 1990-1998, or made a greenfield investment. In the first case, a thorough portfolio-cleaning was done, which resulted in productivity growth (Lengyel - Cadil 2009). In the other case, big investments in new sectors for the country (e.g. in ICT) probably increased labour and productivity growth in the region (Iwasaki et al. 2009). On the other hand, the output of domestic companies increased slower than their registered capital in the period. What we face here is again the phenomenon of duality in transition economies, which has been described repeatedly (Szanyi 2003; Lengyel - Leydesdorff 2011). Consequently, localisation economies are likely to prevail in Hungary due to foreign-owned companies. But these investments hardly affected productivity growth in co-located domestic companies.

In sum, the phenomenon of the dual economy becomes visible when regional productivity growth is in focus. While foreign investments enhance regional productivity, domestic companies do not improve their productivity accordingly and retard regional economic growth.

\subsection{Productivity growth}

Our results suggest that neither regional concentration, nor regional specialisation had a positive effect on regional productivity growth. In contrast, the regional concentration of industries negatively affected labour productivity growth and total factor productivity growth in the Hungarian regions. The formerly demonstrated controversial impact of foreign-owned and domestic capital disappears when other variables are introduced in productivity growth models. The results are summarised in Table 4. 
Table 4

Productivity

\begin{tabular}{|c|c|c|c|c|c|}
\hline \multirow[t]{2}{*}{ Models } & \multicolumn{5}{|c|}{ Labour productivity } \\
\hline & {$[1]$} & {$[2]$} & {$[3]$} & {$[4]$} & {$[5]$} \\
\hline SPECEMP & $\begin{array}{l}-0.063 \\
(-1.43)\end{array}$ & $\begin{array}{l}-5.04 \mathrm{E}-05 \\
(-0.001)\end{array}$ & $\begin{array}{l}-0.042 \\
(-0.68)\end{array}$ & $\begin{array}{r}0.091 \\
(1.38)\end{array}$ & $\begin{array}{c}0.122 \\
(1.50)\end{array}$ \\
\hline SPECORG & $\begin{array}{c}0.062 \\
(1.15)\end{array}$ & $\begin{array}{l}0.0185 \\
(0.34)\end{array}$ & $\begin{array}{l}-0.070 \\
(-0.87)\end{array}$ & $\begin{array}{l}-0.109 \\
(-1.34)\end{array}$ & $\begin{array}{l}-0.071 \\
(-0.63)\end{array}$ \\
\hline CONCSALE & $\begin{array}{l}1.385^{* * *} \\
(10.97)\end{array}$ & $\begin{array}{l}0.895^{* * *} \\
(6.26)\end{array}$ & $\begin{array}{l}1.532 * * * \\
(7.31)\end{array}$ & $\begin{array}{l}0.916^{* * *} \\
(3.85)\end{array}$ & $\begin{array}{c}0.249 \\
(0.82)\end{array}$ \\
\hline CONCIND & $\begin{array}{l}-3.535^{* * * *} \\
(-6.37)\end{array}$ & $\begin{array}{l}-3.428 * * * \\
(-6.23)\end{array}$ & $\begin{array}{l}-5.190 * * * \\
(-6.91)\end{array}$ & $\begin{array}{l}-5.682 * * * \\
(-7.59)\end{array}$ & $\begin{array}{l}-5.105^{* * *} \\
(-5.83)\end{array}$ \\
\hline CONCEMP & $\begin{array}{l}1.0143^{* * * *} \\
(25.35)\end{array}$ & $\begin{array}{l}1.030 * * * \\
(25.67)\end{array}$ & $\begin{array}{l}1.031 * * * \\
(19.85)\end{array}$ & $\begin{array}{l}1.287^{* * * *} \\
(18.56)\end{array}$ & $\begin{array}{l}1.33 * * * \\
(16.56)\end{array}$ \\
\hline DOMINI & & $\begin{array}{l}-0.105^{* * *} \\
(-7.76)\end{array}$ & $\begin{array}{l}-0.067 * * \\
(-2.24)\end{array}$ & $\begin{array}{r}0.055 \\
(1.41)\end{array}$ & $\begin{array}{r}0.075 \\
(1.57)\end{array}$ \\
\hline FORINI & & $\begin{array}{c}0.004 \\
(0.64)\end{array}$ & $\begin{array}{l}0.112^{* * * *} \\
(5.65)\end{array}$ & $\begin{array}{l}0.120^{* * *} \\
(5.53)\end{array}$ & $\begin{array}{l}0.153^{* * * *} \\
(5.84)\end{array}$ \\
\hline FORGRO & & & $\begin{array}{l}0.077^{* * * *} \\
(3.99)\end{array}$ & $\begin{array}{l}0.078^{* * *} \\
(3.86)\end{array}$ & $\begin{array}{l}0.103^{* * * *} \\
(4.25)\end{array}$ \\
\hline DOMGRO & & & $\begin{array}{l}0.103^{* * * *} \\
(2.86)\end{array}$ & $\begin{array}{l}0.165^{* * *} \\
(4.09)\end{array}$ & $\begin{array}{l}0.239 * * * \\
(4.83)\end{array}$ \\
\hline EMPLINI & & & & $\begin{array}{l}-0.418^{* * *} \\
(-5.57)\end{array}$ & $\begin{array}{l}-0.525^{* * *} \\
(-5.95)\end{array}$ \\
\hline EMPLGRO & & & & $\begin{array}{r}0.027 \\
(0.38)\end{array}$ & $\begin{array}{l}-0.127 \\
(-1.42)\end{array}$ \\
\hline REGDIV & & & & $\begin{array}{c}0.000 \\
(0.03)\end{array}$ & $\begin{array}{r}0.000 \\
(0.02)\end{array}$ \\
\hline POPDENS & & & & $\begin{array}{l}0.260^{* * *} \\
(3.85)\end{array}$ & $\begin{array}{l}0.236^{* * * *} \\
(2.72)\end{array}$ \\
\hline const & $\begin{array}{l}-2.261 * * * \\
(-19.67)\end{array}$ & $\begin{array}{l}-1.009 * * * \\
(-5.14)\end{array}$ & $\begin{array}{l}-2.833^{* * *} \\
(-7.44)\end{array}$ & $\begin{array}{l}-2.518 * * * \\
(-6.34)\end{array}$ & $\begin{array}{l}-2.405^{* * *} \\
(-4.94)\end{array}$ \\
\hline$N$ & 2731 & 2731 & 1311 & 1310 & 837 \\
\hline Adj. $R^{2}$ & 0.398 & 0.412 & 0.506 & 0.521 & 0.555 \\
\hline$F$ & $361.70 * * *$ & $272.94 * * *$ & $148.33 * * *$ & $108.83 * * *$ & $79.11 * * *$ \\
\hline
\end{tabular}

Note: All the models are estimated using OLS regression. $t$-statistics are reported in parentheses beneath regression co-efficients. ${ }^{* *}, * *$, and $*$ denote statistical significance at the $1 \%, 5 \%$ lev els, respectively. For definitions of variables, see Table 1 . 
growth models

\begin{tabular}{|c|c|c|c|c|c|}
\hline \multirow[t]{2}{*}{ Models } & \multicolumn{5}{|c|}{ Total factor productivity } \\
\hline & {$[6]$} & {$[7]$} & {$[8]$} & [9] & {$[10]$} \\
\hline SPECEMP & $\begin{array}{l}-0.099 * * \\
(-2.17)\end{array}$ & $\begin{array}{l}-0.115^{* *} \\
(-2.48)\end{array}$ & $\begin{array}{l}-0.125^{*} \\
(-1.93)\end{array}$ & $\begin{array}{r}0.065 \\
(0.97)\end{array}$ & $\begin{array}{r}0.118 \\
(1.42)\end{array}$ \\
\hline SPECORG & $\begin{array}{l}0.102 * \\
(1.84)\end{array}$ & $\begin{array}{l}0.110^{* *} \\
(1.98)\end{array}$ & $\begin{array}{c}-0.042 \\
(-0.50)\end{array}$ & $\begin{array}{l}-0.107 \\
(-1.28)\end{array}$ & $\begin{array}{c}-0.086 \\
(-0.74)\end{array}$ \\
\hline CONCSALE & $\begin{array}{l}1.310^{* * *} \\
(9.94)\end{array}$ & $\begin{array}{l}1.427 * * * \\
(9.33)\end{array}$ & $\begin{array}{l}1.794 * * * \\
(8.23)\end{array}$ & $\begin{array}{l}1.023^{* * *} \\
(4.19)\end{array}$ & $\begin{array}{c}0.365 \\
(1.18)\end{array}$ \\
\hline CONCIND & $\begin{array}{l}-3.885^{* * *} \\
(-6.62)\end{array}$ & $\begin{array}{l}-3.726^{* * * *} \\
(-6.34)\end{array}$ & $\begin{array}{l}-4.977 * * * \\
(-6.38)\end{array}$ & $\begin{array}{l}-5.349 * * * \\
(-6.96)\end{array}$ & $\begin{array}{l}-4.733^{* * *} \\
(-5.29)\end{array}$ \\
\hline CONCEMP & $\begin{array}{l}1.018^{* * *} \\
(24.54)\end{array}$ & $\begin{array}{l}0.988^{* * *} \\
(23.49)\end{array}$ & $\begin{array}{l}0.909 * * * \\
(16.84)\end{array}$ & $\begin{array}{l}1.283^{* * *} \\
(18.01)\end{array}$ & $\begin{array}{l}1.303^{* * * *} \\
(15.78)\end{array}$ \\
\hline DOMINI & & $\begin{array}{l}-0.016 \\
(-1.09)\end{array}$ & $\begin{array}{l}-0.050 \\
(-1.62)\end{array}$ & $\begin{array}{l}0.083^{* *} \\
(2.09)\end{array}$ & $\begin{array}{l}0.109 * * \\
(2.23)\end{array}$ \\
\hline FORINI & & $\begin{array}{l}0.031 * * * \\
(4.44)\end{array}$ & $\begin{array}{l}0.149^{* * *} \\
(7.26)\end{array}$ & $\begin{array}{l}0.149 * * * \\
(6.70)\end{array}$ & $\begin{array}{l}0.184 * * * \\
(6.87)\end{array}$ \\
\hline FORGRO & & & $\begin{array}{l}-8.8 \mathrm{E}-05 \\
(-0.00)\end{array}$ & $\begin{array}{l}-0.022 \\
(-1.06)\end{array}$ & $\begin{array}{c}0.004 \\
(0.18)\end{array}$ \\
\hline DOMGRO & & & $\begin{array}{l}-0.039 \\
(-1.05)\end{array}$ & $\begin{array}{l}-0.010 \\
(-0.249)\end{array}$ & $\begin{array}{r}0.073 \\
(1.44)\end{array}$ \\
\hline EMPLINI & & & & $\begin{array}{l}-0.454 * * * \\
(-5.90)\end{array}$ & $\begin{array}{l}-0.579 * * * \\
(-6.41)\end{array}$ \\
\hline EMPLGRO & & & & $\begin{array}{l}0.322 * * * \\
(4.38)\end{array}$ & $\begin{array}{c}0.142 \\
(1.55)\end{array}$ \\
\hline REGDIV & & & & $\begin{array}{l}0.000 \\
(0.35)\end{array}$ & $\begin{array}{c}0.000 \\
(0.10)\end{array}$ \\
\hline POPDENS & & & & $\begin{array}{l}0.260 * * * \\
(3.75)\end{array}$ & $\begin{array}{l}0.221 * * \\
(2.49)\end{array}$ \\
\hline const & $\begin{array}{l}-2.520 * * * \\
(-21.18)\end{array}$ & $\begin{array}{l}-2.524 * * * \\
(-11.92)\end{array}$ & $\begin{array}{l}-3.243 * * * \\
(-8.20)\end{array}$ & $\begin{array}{l}-3.076^{* * *} \\
-7.54\end{array}$ & $\begin{array}{l}-2.860 * * * \\
-5.74\end{array}$ \\
\hline$N$ & 2706 & 2706 & 1311 & 1310 & 837 \\
\hline Adj. $R^{2}$ & 0.377 & 0.382 & 0.477 & 0.505 & 0.525 \\
\hline$F$ & $328.045^{* * *}$ & $238.675^{* * *}$ & $132.218^{* * *}$ & $101.89 * * *$ & $70.17 * * *$ \\
\hline
\end{tabular}


Concentration variables have a stable and significant effect on both labour productivity and TFP productivity growth. CONCSALE affects productivity growth positively. Since it is a Hirschman-Herfindahl index based on national market-share distributions, it indicates that a more concentrated market-share favours productivity growth in the region. CONCEMP has a positive significant co-efficient in all models. This indicator is the average firm in the industry-region, thus its impact suggests that the bigger the firms in the region, the higher the productivity growth. CONCIND has a stable, negative, very strong effect on both labour and total factor productivity growth. This indicator is an Ellison-Glaeser $\gamma$ index based on regional distribution of industries across the nation, therefore the negative co-efficient implies that the more the industry is concentrated in certain regions, the smaller the productivity growth. This latter result is very interesting because we expected that regional concentration of industries would favour productivity growth. However, the negative effect of CONCIND suggests that the more scattered the industry, the higher the productivity growth. The robustness of the latter results has been confirmed by splitting the observations into two parts. We found a negative effect of CONCEMPL in the sample of industry-regions with a SPECORG indicator lower than 1, and the sample of industry-regions with SPECORG higher than 1 as well.

Specialisation variables do not have significant coefficients in labour productivity models (Models 1-5) but SPECEMPL affects TFP growth negatively in a significant manner in Models 6-8. In a previous paper, we have found a significant positive effect of regional specialisation on TFP growth that might be eliminated by the concentration variables used in this paper (Lengyel et al. 2010).

Ownership variables have lost the majority of their overwhelmingly controversial effect on growth (demonstrated in Table 3) when accompanied by concentration and specialisation variables. However, DOMINI has negative co-efficient values in Models 2-3 and 7-8, while FORINI's impact is positive and significant in the vast majority of models. FORGRO and DOMGRO have a positive and significant effect on labour productivity, but do not affect total factor productivity growth significantly.

Control variables have effects with diverse signs and significance levels. The co-efficient of EMPLINI is significant and strongly negative in all models, suggesting that a high level of initial employment retards both labour and total factor productivity growth. This implies that the higher the absolute level of employment, the slower the productivity growth. EMPLGRO, that will be the dependent variable in Table 5, affects total factor productivity growth positively and significantly in Model 9, suggesting that employment growth has a positive impact on total factor productivity growth. POPDENS has a positive and significant co-effi- 
cient in Models 4-5 and 9-10, indicating that urbanisation has positively contributed to productivity growth.

In sum, concentration variables dominate the productivity growth models and suggest that regional productivity growth depends on a concentrated sales structure and employment concentration in big firms. The findings suggest that growth is more likely to occur in regions, where big firms are dominant in the given sector. Moreover, regional specialisation had no or even a negative effect on growth and regional growth was significantly slower in industries that were concentrated in certain regions initially than in more scattered ones. Therefore, neither the specialisation of regions, nor the regional concentration of industries is associated with productivity growth in Hungary. The first hypothesis is false.

\subsection{Employment growth}

Patterns of regional employment growth in Hungary differ from productivity growth in all areas of our explanatory variables. Regional specialisation seems to affect employment growth negatively and this effect is much more stable compared to the ones in productivity growth models. Concentration variables have a significant effect, but CONCEMP has negative coefficients, unlike in productivity models. Ownership variables depict a somewhat different picture as well, in which domestic investment enhances employment growth more strongly than foreign investments.

Concentration variables impact regional employment growth to a lesser extent than productivity growth. CONCSALE, the market-share concentration, influences employment growth positively, but this effect is not stable because the introduction of control variables eliminates it in Models 3 and 4. The effect of CONCEMP, unlike in productivity models, is negative and stably significant. Employment growth is slower in regions with bigger firms and regions with smaller firms exhibit a fast employment growth. The co-efficient of CONCIND is negative and significant in all the models. This suggests that the dispersion of industry in certain regions favours growth because the employment growth was slower in industries in which firms tend to locate close to each other and CONCIND is high. To test the robustness of this result, we also carried out two analyses. First, an additional regression found a negative effect of the raw concentration of employees (Ellison-Glaeser G) on regional employment growth. Second, we split the data into two samples: industry-regions with SPECORG lower than 1 and industry-regions with SPECORG higher than 1. CONCEMPL has a negative effect on regional employment growth in both samples. 
Table 5

Employment growth models

\begin{tabular}{|c|c|c|c|c|}
\hline & {$[1]$} & {$[2]$} & {$[3]$} & {$[4]$} \\
\hline SPECEMP & $\begin{array}{l}-0.119 * * * \\
(-6.84)\end{array}$ & $\begin{array}{l}-0.165^{* * *} \\
(-6.86)\end{array}$ & $\begin{array}{l}-0.126^{* * *} \\
(-4.81)\end{array}$ & $\begin{array}{l}-0.128^{* * *} \\
(-3.93)\end{array}$ \\
\hline SPECORG & $\begin{array}{l}-0.082 * * * \\
(-3.82)\end{array}$ & $\begin{array}{l}0.057^{*} \\
(1.85)\end{array}$ & $\begin{array}{c}0.014 \\
(0.44)\end{array}$ & $\begin{array}{l}-0.009 \\
(-0.21)\end{array}$ \\
\hline CONCSALE & $\begin{array}{l}0.223^{* * * *} \\
(4.57)\end{array}$ & $\begin{array}{l}0.281 * * * \\
(3.45)\end{array}$ & $\begin{array}{l}-0.069 \\
(-0.75)\end{array}$ & $\begin{array}{l}-0.060 \\
(-0.50)\end{array}$ \\
\hline CONCIND & $\begin{array}{l}-0.986 * * * \\
(-5.00)\end{array}$ & $\begin{array}{l}-1.175^{* * *} \\
(-4.25)\end{array}$ & $\begin{array}{l}-0.581^{* *} \\
(-1.98)\end{array}$ & $\begin{array}{l}-0.756^{* *} \\
(-2.19)\end{array}$ \\
\hline CONCEMP & $\begin{array}{l}-0.360 * * * \\
(-22.69)\end{array}$ & $\begin{array}{l}-0.322 * * * \\
(-16.16)\end{array}$ & $\begin{array}{l}-0.262 * * * \\
(-8.90)\end{array}$ & $\begin{array}{l}-0.252 * * * \\
(-7.12)\end{array}$ \\
\hline DOMINI & & $\begin{array}{r}0.013 \\
(1.16)\end{array}$ & $\begin{array}{l}0.070 * * * \\
(4.62)\end{array}$ & $\begin{array}{l}0.088 * * * \\
(4.76)\end{array}$ \\
\hline FORINI & & $\begin{array}{l}0.043^{* * *} \\
(5.78)\end{array}$ & $\begin{array}{l}0.051^{* * *} \\
(5.88)\end{array}$ & $\begin{array}{l}0.037^{* * *} \\
(3.45)\end{array}$ \\
\hline FORGRO & & $\begin{array}{l}0.079 * * * \\
(10.59)\end{array}$ & $\begin{array}{l}0.090^{* * * *} \\
(12.14)\end{array}$ & $\begin{array}{l}0.087^{* * *} \\
(9.75)\end{array}$ \\
\hline DOMGRO & & $\begin{array}{l}0.140^{* * *} \\
(10.10)\end{array}$ & $\begin{array}{l}0.182 * * * \\
(12.29)\end{array}$ & $\begin{array}{l}0.192^{* * *} \\
(10.62)\end{array}$ \\
\hline EMPLINI & & & $\begin{array}{l}-0.164 * * * \\
(-5.58)\end{array}$ & $\begin{array}{l}-0.164 * * * \\
(-4.63)\end{array}$ \\
\hline TOTALGRO & & & $\begin{array}{r}0.011 \\
(0.22)\end{array}$ & $\begin{array}{r}0.042 \\
(0.44)\end{array}$ \\
\hline WAGE & & & $\begin{array}{l}0.060 * * \\
(2.04)\end{array}$ & $\begin{array}{l}0.093^{* *} \\
(2.36)\end{array}$ \\
\hline REGDIV & & & $\begin{array}{r}0.000 \\
(1.60)\end{array}$ & $\begin{array}{r}0.000 \\
(1.34)\end{array}$ \\
\hline POPDENS & & & $\begin{array}{r}0.019 \\
(0.69)\end{array}$ & $\begin{array}{c}0.016 \\
(0.41)\end{array}$ \\
\hline TFPGRO & & & $\begin{array}{l}0.044 * * * \\
(4.30)\end{array}$ & $\begin{array}{c}0.019 \\
(1.45)\end{array}$ \\
\hline const & $\begin{array}{l}1.156^{* * *} \\
(24.97)\end{array}$ & $\begin{array}{l}0.282^{*} \\
(1.90)\end{array}$ & $\begin{array}{r}0.021 \\
(0.10) \\
\end{array}$ & $\begin{array}{l}-0.274 \\
(-1.04) \\
\end{array}$ \\
\hline$N$ & 3111 & 1404 & 1310 & 837 \\
\hline Adj. $R^{2}$ & 0.370 & 0.503 & 0.542 & 0.562 \\
\hline$F$ & $366.46^{* * *}$ & $159.36^{* * *}$ & $104.55^{* * *}$ & $72.74 * * *$ \\
\hline
\end{tabular}

Note: All the models are estimated using OLS regression. $t$-statistics are reported in parentheses beneath regression co-efficients. ${ }^{* * *}, * *$, and $*$ denote statistical significance at the $1 \%, 5 \%$ levels, respectively. For definitions of variables, see Table 1.

Acta Oeconomica 64 (2014) 
Only SPECEMPL has a significant and stable effect from the set of cluster variables. Its negative co-efficient suggests that regional specialisation, regarding employment profile, has set future employment growth back. The same effect was found by Glaeser et al. (1992). Static variables of concentration had a negative effect on regional growth in the ICT industry of the Netherlands as well (van Oort et al. 2005; Weterings 2005). However, our SPECEMPL coefficients show a much more stable negative relation between the initial state of regional concentration and employment growth in Hungary than was reported in the above-mentioned papers.

Ownership variables shed a different light on regional employment growth than we witnessed in productivity models: all these variables have positive and mostly significant coefficients here. Investments, regardless of whether domestic or foreign, are expected to result in employment growth in the region. However, DOMGRO has repeatedly a higher impact on growth than FORGRO, which suggests that domestic investments might be more important in employment creation than foreign investments.

The initial state of employment, EMPLINI, has a significant and negative effect on growth. This suggests that the regional spread of industries dominated employment growth in the period. However, the WAGE variable has a positive and significant effect, suggesting that growth was more dynamic in regions where employees received relatively high salaries on average. Therefore, one cannot claim that regional employment growth has taken place in Hungary in the pure form as spatial equilibrium models suggest.

To sum up, regional restructuring has occurred in Hungary, in which employment growth was negatively influenced by the initial level of the regional concentration of industries. Regional specialisation has retarded employment; regions that were specialised initially have lost from their dynamics. The second hypothesis is false, too.

\section{CONCLUSIONS AND DISCUSSION}

Using census-type data of Hungarian firms from between 1998 and 2005, we empirically examined the effect of regional specialisation, the regional concentration of industries, and the impact of firm ownership on the factors of regional economic growth. Our results imply that the agglomeration models that explain regional economic growth in developed countries cannot provide an econometrically confirmed explanation in a country with lagging regions. Hungary faces challenges that typically characterise dual economies and economies in transition. 
The dual structure of the economy was considered with the distinction of foreign- and domestically-owned firms, and the test of their impact on factors of growth. It was shown that the positive effect of foreign-owned capital (both initial and growth) on productivity growth was accompanied by conflicting effects of domestic capital. The initial levels and growth of domestic capital had a negative impact on productivity. The contrasting effect of foreign and domestic capital might also undermine the claim that local knowledge spillovers from MNEs to domestic companies are the primary source of regional economic growth. Therefore, the question has to be raised again how MNEs and foreign direct investment affect regional industrial dynamics and the upgrading or survival of domestic firms.

Regional productivity growth is found to have been unaffected by regional specialisation, but the initial level of the regional concentration of industries has had a very strong and stable negative impact on growth. These findings show that our first hypothesis (H1) is false. However, the role of a concentrated market structure and of large firms in productivity growth is undeniable. The big companies are motivated to locate in less developed economies by low costs, and previously specialised regions with industries that are geographically concentrated were unable to catch up with these dynamics.

Regional specialisation also has a very significant and robust negative effect on regional employment growth, accompanied by a negative impact of the regional concentration of industries. Thus, our second hypothesis (H2) proved to be false, as well. Regions that were initially specialised in an industry and had relatively high employment levels have lost their position.

Regional restructuring during the economic transition in Hungary has resulted in a spatially more concentrated economy because previously industrialised regions have lost their markets, whereas new investments occurred around the agglomeration of the capital and in regions lying between Budapest and the Austrian border. However, industries that were spatially concentrated initially have also retarded regional productivity and employment growth. Only those regions and industries expanded dynamically in which foreign firms invested.

These findings may undermine the efficiency of economic policies favouring regional specialisation - such as cluster policy - in Central and Eastern Europe. These relatively less developed countries are on the periphery of the European Union. Therefore, one cannot expect the same extent of innovation to occur as in central EU agglomerations; standardised production will be located in these peripheral regions, driven by low production costs. This type of production is more probably located in industrial complexes than in pure agglomerations, where the role of technical spillovers is less expressed within localisation economies (McCann et al. 2002). Put differently, knowledge externalities are key ingredients for growth in the core regions of developed countries and investments coming 
from outside the region might determine regional growth in less-developed areas. Consequently, policy-makers both in the EU and in national organisations should be aware of the varying explanatory power of knowledge externalities across regions and cannot take the automatic knowledge spillovers from MNEs to domestic companies for granted. Instead, regional policies should go further after supporting investments and should focus on the interaction between foreign-owned and domestic companies.

\section{REFERENCES}

Acs, Z.J. - O'Gorman, C. - Szerb, L. - Terjesen, S. (2007): Could the Irish Miracle be Repeated in Hungary? Small Business Economics, 28: 123-142.

Audretsch, D.B. - Keilbach, M. (2005): Entrepreneurship Capital and Regional Growth. The Annals of Regional Science, 39: 457-469.

Békés, G. - Kleinert, J. - Toubal, F. (2006): Spillovers from Multinationals to Heterogeneous Domestic Firms: Evidence from Hungary. Discussion Papers, No. 2006/16, Institute of Economics, Hungarian Academy of Sciences.

Beugelsdijk, S. - McCann, P. - Mudambi, R. (2010): Introduction: Place, Space and Organization Economic Geography and the Multinational Enterprise. Journal of Economic Geography, 10: 485-493.

Boschma, R.A. (2005): Proximity and Innovation: A Critical Assessment. Regional Studies, 39: $61-74$.

Capello, R. (2009a): Space, Growth and Development. In: Capello, R. - Nijkamp, P. (eds): Handbook of Regional Growth and Development Theories. Cheltenham: Edward Elgar, pp. 33-52.

Capello, R. (2009b): Spatial Spillovers and Regional Growth: A Cognitive Approach. European Planning Studies, 17: 639-658.

EC (2011): Regional Policy for Smart Growth in Europe 2020. Brussels.

Farkas, P. (2000): The Effects of Foreign Direct Investment on R\&D and Innovation in Hungary. IWE Working Papers, No. 108, Institute for World Economics, Hungarian Academy of Sciences.

Glaeser, E. (2000): The New Economics of Urban and Regional Growth. In: Clark, G.L. - Gertler, M.S. - Feldman, M.P. (eds): The Oxford Handbook of Economic Geography. Oxford: Oxford University Press, pp. 83-98.

Glaeser, E. - Kallal, H.D. - Scheinkman, J.D. - Shleifer, A. (1992): Growth in Cities. Journal of Political Economy, 100: 1126-1152.

Gordon, I.R. - McCann, P. (2000): Industrial Clusters: Complexes, Agglomeration and/or Social Networks? Urban Studies, 37: 513-532.

Gordon, I.R. - McCann, P. (2005): Innovation, Agglomeration, and Regional Development. Journal of Economic Geography, 5: 523-543.

Grosz, A. (2006): Clusterization Processes in the Automotive Industry. Discussion Papers, No. 52, Centre for Regional Studies, Hungarian Academy of Sciences.

Halpern, L. - Muraközy, B. (2007): Does Distance Matter in Spillover? Economics of Transition, 15: 781-805

Henderson, J.V. - Kuncoro, A. - Turner, M. (1995): Industrial Development in Cities. Journal of Political Economy, 103: 1067-1085. 
Iammarino, S. - McCann, P. (2006): The Structure and Evolution of Industrial Clusters: Transactions, Technology and Knowledge Spillovers. Research Policy, 35: 1018-1036.

Isard, W. (1956): Location and Space Economy. Cambridge, MA: The Technology Press of Massachusetts Institute of Technology.

Iwasaki, I. (2007): Corporate Restructuring and the Role of Foreign Direct Investment in Hungary. In: Dallago, B. - Iwasaki, I. (eds): Corporate Restructuring and Governance in Transition Economies. Basingstoke: Palgrave Macmillan, pp. 178-210.

Iwasaki, I. - Csizmadia, P. - Illéssy, M. - Makó, Cs. - Szanyi, M. (2009): The Concentric-Circle Model of FDI Spillover Effects: Estimation Using Hungarian Panel Data. IER Discussion Paper A521, Institute of Economic Research, Hitotsubashi University.

Jacobs, J. (1969): The Economy of Cities. New York: Random House.

Ketels, C. - Sölvell, Ö. (2005): Clusters in the EU 10 New Member Countries. Europe INNOVA, Center for Strategy and Competitiveness, Stockholm.

Krugman, P. (1991): Geography and Trade. Cambridge, MA: MIT Press.

Lengyel, B. - Cadil, V. (2009): Innovation Policy Challenges in Transition Countries: Foreign Business R\&D in the Czech Republic and Hungary. Transition Studies Review, 16: 174-188.

Lengyel, B. - Iwasaki, I. - Szanyi, M. (2010): Industrial Clusters and Regional Economic Growth: Evidence from Hungary. Hitotsubashi Journal of Economics, 51: 149-167.

Lengyel, B. - Leydesdorff, L. (2011): Regional Innovation Systems in Hungary: The Failing Synergy at the National Level. Regional Studies, 45: 677-693.

Lengyel, I. (2003): The Pyramid Model: Enhancing Regional Competitiveness in Hungary. Acta Oeconomica, 53(4): 323-342.

Lengyel, I. (2011): Types of Competitiveness of Hungarian Micro-Regions: Empirical Testing of the Regional Competitiveness Function. Paper prepared for the workshop on 'Regional Innovation and Growth: Theory, Empirics, and Policy Analysis”. 30th March - 1st April, 2011, Pécs, Hungary.

Lorenzen, M. - Mahnke, V. (2002): Global Strategy and the Acquisition of Local Knowledge: How MNCs Enter Regional Knowledge Clusters. DRUID Working Paper, 02-08, Danish Research Unit for Industrial Dynamics, Copenhagen.

Marshall, A. (1890): Principles of Economics. London: Macmillan.

Mates, J. (2010): Innovation in Multinational Enterprises: Organisational, International and Regional Dilemmas. Frankfurt - London: Peter Lang.

McCann, P. - Arita, T. - Gordon, I.R. (2002): Industrial Clusters, Transaction Costs and Institutional Determinants of MNE Location Behaviour. International Business Review, 11: 647-663.

Nakamura, R. - Morrison, P.C.J. (2009): Measuring Agglomeration. In: Capello, R. - Nijkamp, P. (eds): Handbook of Regional Growth and Development Theories. Cheltenham-Northampton: Edward-Elgar, pp. 305-328.

Nobel, R. - Birkinshaw, J. (1998): Innovation in Multinational Corporations: Control and Communication Patterns in International R\&D Operations. Strategic Management Journal, 19: 479-496.

van Oort, F. - van Soest, D. P. - Gerking, S.D. (2005): Dynamic Information Externalities and Employment Growth in the Netherlands. In: Boschma, R.A. - Kloosterman, R.C. (eds): Learning from Clusters: A Critical Assessment from an Economic-Geographical Perspective. Dordrecht: Springer, pp. 303-332.

Parr, J.B. (2002): Missing Elements in the Analysis of Agglomeration Economies. International Regional Science Review, 25: 151-168.

Pavlinek, P. - Smith, A. (1998): Internationalization and Embeddedness in East-Central European Transition: The Contrasting Geographies of Inward Investment in the Czech and Slovak Republics. Regional Studies, 32: 619-638.

Acta Oeconomica 64 (2014) 
Petrakos, G. (2001): Patterns of Regional Inequality in Transition Economies. European Planning Studies, 9: 359-383.

Phelps, N.A. (2004): Clusters, Dispersion and the Spaces in between: For an Economic Geography of the Banal. Urban Studies, 41: 971-989.

Phelps, N.A. (2008): Cluster or Capture? Manufacturing Foreign Direct Investment, External Economies and Agglomeration. Regional Studies, 42: 457-473.

Porter, M. (1990): The Competitive Advantage of Nations. New York: The Free Press.

Porter, M. (2003): The Economic Performance of Regions. Regional Studies, 37: 549-578.

Radosevic, S. (2002): Regional Innovation Systems in Central and Eastern Europe: Determinants, Organizers and Alignments. Journal of Technology Transfer, 27: 87-96.

Ratanawaraha, A. - Polenske, K.R. (2007): Measuring the Geography of Innovation: A Literature Review. In: Polenske, K.R. (ed): The Economic Geography of Innovation. Cambridge: Cambridge University Press, pp. 30-59.

Romer, P. (1986): Increasing Returns and Long-Run Growth. Journal of Political Economy, 94: $1002-1037$.

Sjöholm, F. (1999): Productivity Growth in Indonesia: The Role of Regional Characteristics and Direct Foreign Investment. Economic Development and Cultural Change, 47: 559-584.

Szanyi, M. (2003): An FDI-Based Development Model for Hungary - New Challenges? Working Paper, 141, Institute for World Economics, Hungarian Academy of Sciences.

Szanyi, M. - Iwasaki, I. - Csizmadia, P. - Illésy, M. - Makó, Cs. (2011): Cluster Development in Hungary: Searching for a 'Critical Mass' of Business via Cluster Mapping. In: Dallago, B. Guglielmetti, C. (eds): Local Economies and Global Competitiveness. Basingstoke: Palgrave Macmillan, pp. 113-133.

UNCTAD (2005): World Investment Report 2005: Transnational Corporations and the Internationalization of $R \& D$. New York - Geneva: United Nations.

Varga, A. (2007): Localized Knowledge Inputs and Innovation: The Role of Spatially Mediated Knowledge Spillovers in Hungary. Acta Oeconomica, 57(1): 1-20.

Varga, A. - Schalk, H.J. (2004): Knowledge Spillovers, Agglomeration and Macroeconomic Growth: An Empirical Approach. Regional Studies, 38: 977-989.

Weterings, A. (2005): The Spatial Clustering of Knowledge-Intensive Services: Computing Services in the Netherlands. In: Boschma, R.A. - Kloosterman, R.C. (eds): Learning from Clusters. A Critical Assessment from an Economic-Geographical Perspective. Dordrecht: Springer, pp. 275-302.

Young, S. - Hood, N. - Peters, E. (1994): Multinational Enterprises and Regional Economic Development. Regional Studies, 28: 657-677. 


\section{APPENDIX}

\section{Appendix 1: Estimations}

The regional productivity growth models we regress growth in Labour Productivity (LPGRO) and Total Factor Productivity (TFPGRO) of firms operating in the $i$ th industry of the $r$ th region into the above independent variables using the formula:

$$
\begin{aligned}
& \ln \frac{\mathrm{y}_{\mathrm{ir} 05}}{\mathrm{y}_{\mathrm{ir} 98}}=\alpha+\beta \cdot \text { SPECEMPL }_{\mathrm{ir} 98}+\gamma \cdot \text { SPECORG }_{\mathrm{ir} 98}+\delta \cdot \text { CONCSALE }_{\mathrm{ir} 98}+\theta \cdot \\
& \cdot \text { CONCIND }_{\mathrm{i} 98}+\mu \cdot \text { CONCEMP }_{\mathrm{ir} 98}+\rho \cdot \text { DOMINI }_{\mathrm{ir} 98}+\sigma \cdot \text { FORINI }_{\mathrm{ir} 98}+\tau \cdot(1) \\
& \cdot \text { DOMGRO }_{\mathrm{ir} 98}+\varphi \cdot \text { FORGRO }_{\mathrm{ir} 98}+\sum_{\mathrm{k}=1}^{\mathrm{m}} v_{\mathrm{k}} \cdot \mathrm{x}_{\mathrm{k}, \mathrm{r} \text { 98 }}+\varepsilon_{\mathrm{ir}}
\end{aligned}
$$

where $\alpha$ is a constant term, $\beta, \gamma, \delta, \theta, \mu, \rho, \sigma, \tau, \varphi$, and $v$ are parameters of variables, $\mathrm{x}_{\mathrm{k}}$ is the $k$ th control variable and $\varepsilon$ is an error term.

In the next step, we regress to Employment Growth (EMPLGRO) in the $i$ th industry of the $r$ th region using the formula:

$$
\begin{aligned}
& \text { EMPLGRO }=\alpha+\beta \cdot \text { SPECEMPL }_{\mathrm{ir} 98}+\delta \cdot \operatorname{CONCSALE}_{\mathrm{ir} 98}+\tau \cdot \\
& \cdot \text { CONCIND }_{\mathrm{i} 98}+\mu \cdot \text { CONCEMP }_{\mathrm{ir} 98}+\rho \cdot \text { DOMINI }_{\mathrm{ir} 98}+\sigma \cdot \text { FORINI }_{\mathrm{ir} 98}+\tau \cdot(2) \\
& \cdot \text { DOMGRO }_{\mathrm{ir} 98}+\varphi \cdot \text { FORGRO }_{\mathrm{ir} 98}+\sum_{\mathrm{k}=1}^{\mathrm{m}} w_{\mathrm{k}} \cdot \mathrm{z}_{\mathrm{k}, \mathrm{ir} 98}+\varepsilon_{\mathrm{ir}}
\end{aligned}
$$

where $\alpha$ is a constant term, $\beta, \gamma, \delta, \theta, \mu, \rho, \sigma, \tau, \varphi$, and $\omega$ are parameters of variables, $\mathrm{z}_{1}$ is the 1 th control variable and $\varepsilon$ is an error term. 


\section{Appendix 2: Representation of sub-regions in the regression models}
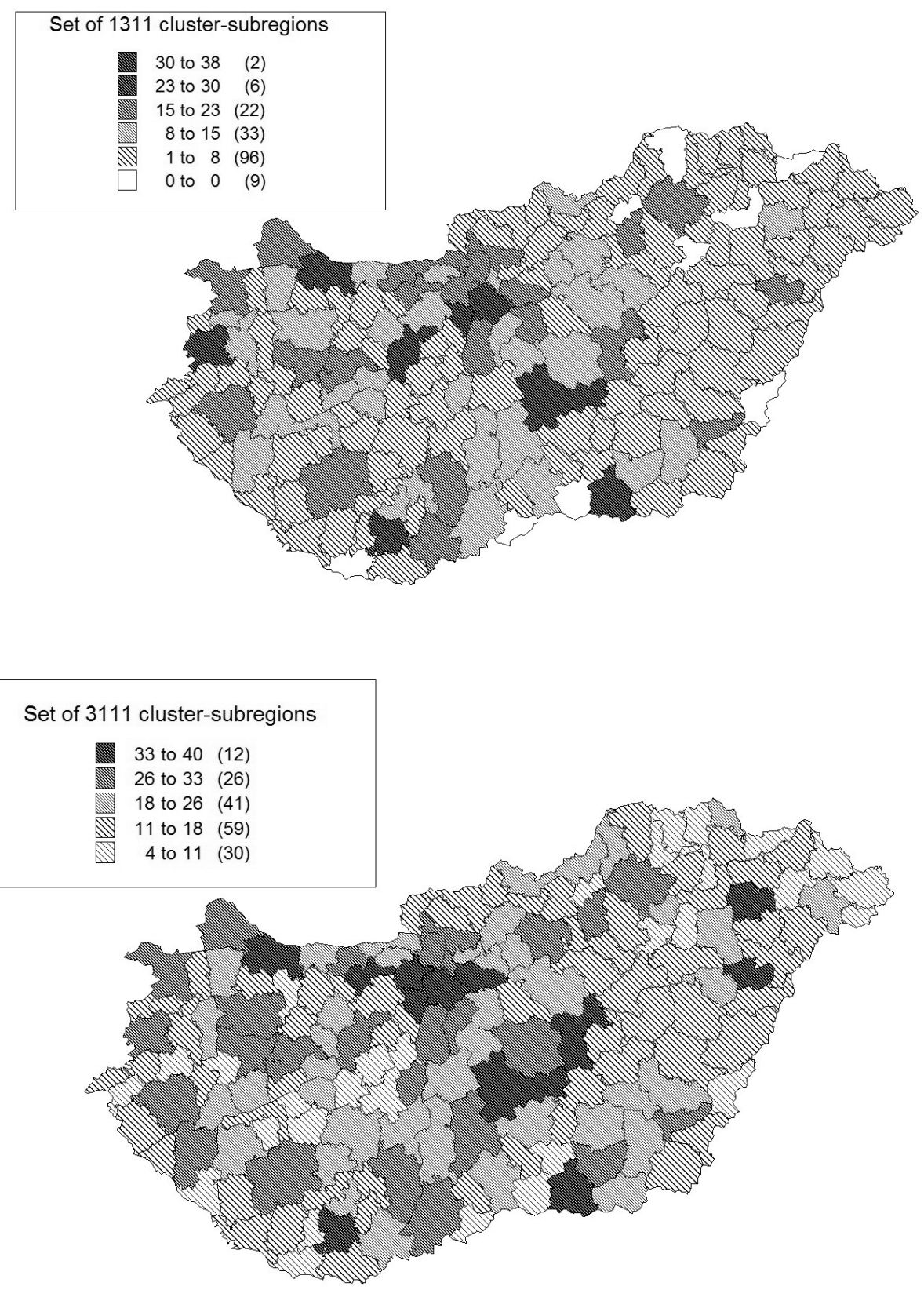

Acta Oeconomica 64 (2014) 

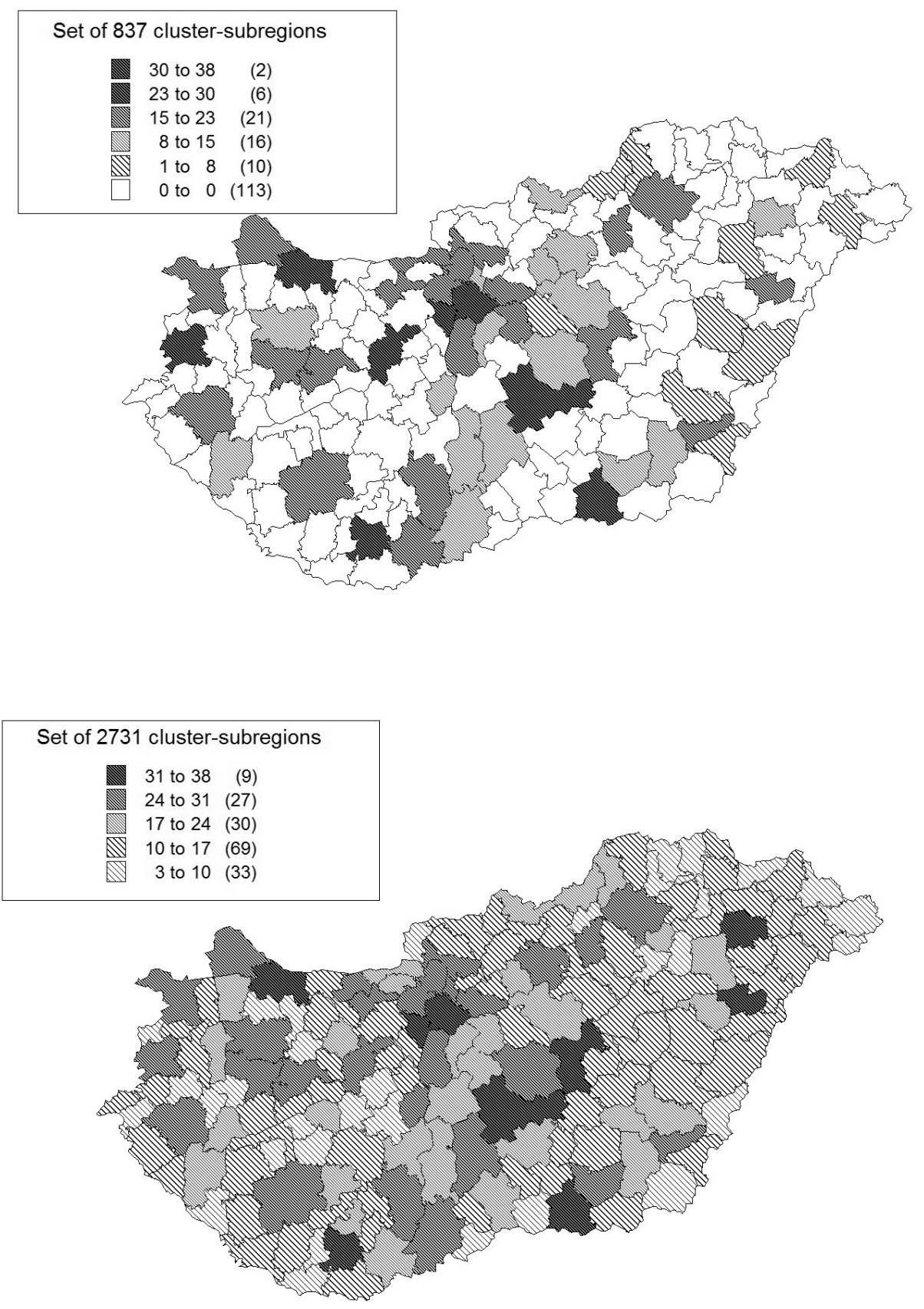

Acta Oeconomica 64 (2014) 
Appendix 3: Representation of industries in the regression models

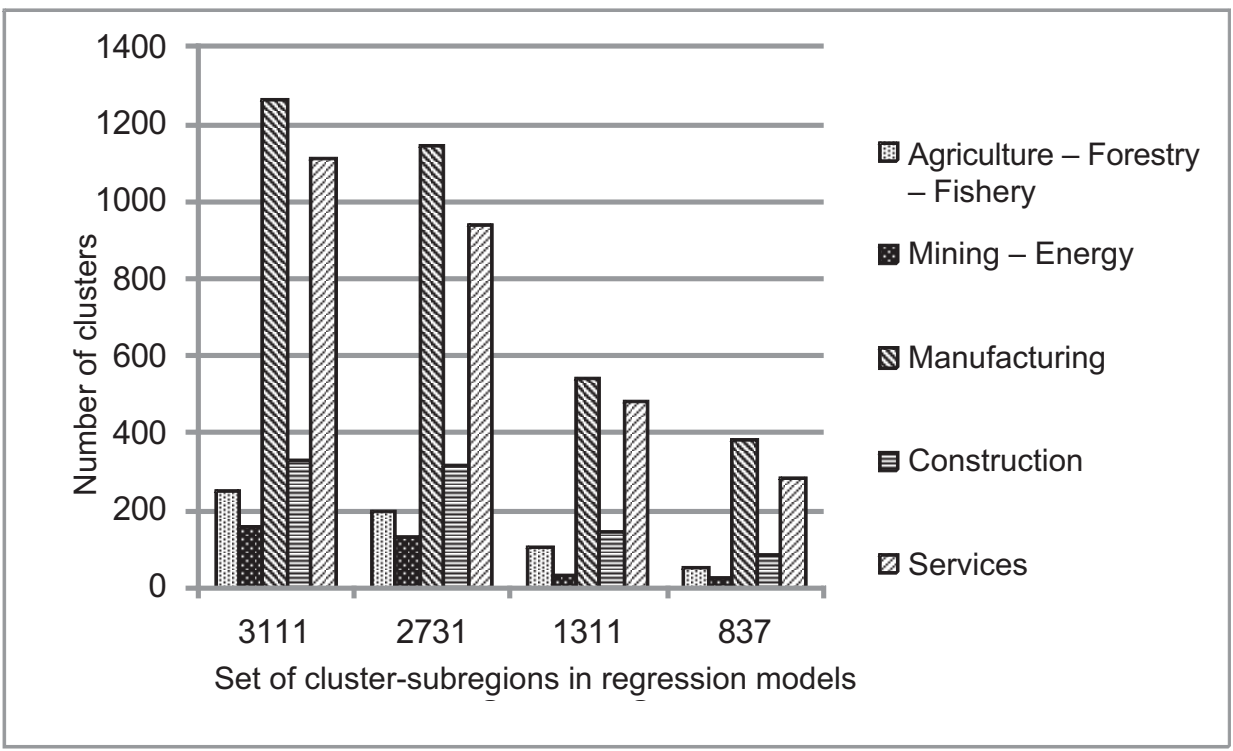

